DOI: 10.15290/bsp.2016.21.en.02

\author{
Wojciech Zalewski \\ University of Gdańsk \\ wojciech.zalewski@prawo.ug.edu.pl
}

\title{
Restorative Justice - a Form of Deliberative Democracy?
}

\begin{abstract}
Modern democracy is in crisis. Citizens feel alienated, overlooked and unappreciated. The way out of the crisis, in the opinion of many, is increasing the public role in democratic processes through civil participation. Citizens want to be involved not only in the process of legislation, but also in the application of the law. Today the court is no longer Dworkin's "capital of the law". There are alternatives to judicial resolutions, including restorative justice. Restorative justice is one of the modern forms of implementation of deliberative democracy's postulates.
\end{abstract}

Keywords: restorative justice, deliberative democracy, criminal law

Each government system must be legitimized, that is authorized to act. Legitimization is considered as "ruling authority's entitlement to take binding decisions

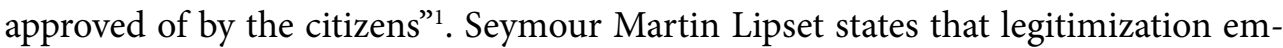
braces the system's capacity to create and maintain the belief that existing political institutions are good for the society. Individual groups find a political system legitimate if the system's values correspond to their values ${ }^{2}$. Legitimization to punish may derive from various sources: it was once believed it came from God, through inheritance or conquest. Currently, however, people expect rationality in punishing and legitimizing authority ${ }^{3}$. Authority is, most of all, requested to be justified by a social agreement and democracy.

Jean Jacques Rousseau pointed out that legitimate authority means something different from merely power or compulsion. He claimed that "The strongest is never strong enough to be always the master, unless he transforms strength into right, and

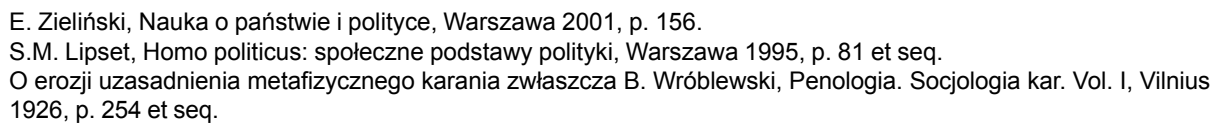


obedience into duty". Furthermore: "Since no man has a natural authority over his fellow, and force creates no right, we must conclude that conventions form the basis of all legitimate authority among men"4. Freedom, however, is not given away for free. Freedom is inherent to man. "To renounce liberty is to renounce being a man, to surrender the rights of humanity and even its duties". Rousseau believed the Social Contract (contrat social) provided a solution to the problem of finding such a form of association which would "defend and protect with the whole common force the person and goods of each associate, and in which each, while uniting himself with all, may still obey himself alone, and remain as free as before". The clauses of the Social Contract may actually be reduced to one and fundamental issue - total alienation of each associate, together with all his rights, to the whole community; for, in the first place, as each gives himself absolutely, the conditions are the same for all; and, this being so, no one has any interest in making them burdensome to others ${ }^{5}$. Rousseau believed the alienation being without reserve, the union is as perfect as it can be, and no associate has anything more to demand ${ }^{6}$. The contract is clear, though absolute: all for everything.

Recalling philosophical pillars of contemporary democracy is necessary because they also entail essential conclusions about sources, boundaries and justification of state punishment ${ }^{7}$. No better system of making and applying law than a democratic state has been conceived so far. Furthermore, democracy is based on a society following a specific system of values. 20th century experiences, which are often very painful, confirm that there is no law and democratic state without the society believing in and defending them. As Hannah Arendt noticed: "Not the loss of specific rights but the loss of a community willing and able to guarantee any right whatsoever has been the calamity". At present, it is accurately claimed that democracy allows to implement values crucial for a social life. What is more, it happens so because democracy is not a neutral political system. Democracy institutionalizes in politics a more ethical treatment of individuals than the political alternatives to democracy, in particular autocracy and oligarchy ${ }^{9}$. Lack of citizens' engagement in democratic processes threatens democracy. People feel alienated and ignored ${ }^{10}$ because their opinion counts only during the election. It is a considerable threat. Democracy is not a system given for ever. We must cherish it and toil to build social capital. As John Braithwaite accu-

4 Comp.: J.J. Rousseau, Umowa społeczna, przełożył i objaśnił dr Antoni Peratiatkowicz prof. Uniw. Poznańskiego, Poznań 1920, p. 14-15.

5 Comp.: J.J. Rousseau, Umowa społeczna, op. cit., p. 20-21.

$6 \quad$ Ibidem.

7 Comp. A. Peretiatkowicz, Filozofia prawa Jana Jakóba Rousseau'a, Kraków 1913, p. 218 et seq. (particularly Chapter V titled Criminal Philosophy).

8 H. Arendt, Korzenie totalitaryzmu, vol. 1, Warszawa 1993, p. 325.

9 Comp. A. Gutmann, Identity in Democracy, Princeton 2004, p. 27; Comp. more: B. Wojciechowski, Interkulturowe prawo karne. Filozoficzne podstawy karania w wielokulturowych społeczeństwach demokratycznych, Toruń 2009, p. 128 et seq.

10 Comp. Particularly: R.D. Putnam, Samotna gra w kręgle. Upadek i odrodzenie wspólnot lokalnych w Stanach Zjednoczonych, Warszawa 2008. 
rately noticed "people are not born democrats" 11 but they learn various forms of democratic participation. History knows many forms of legitimacy but in today's world democracy is its only serious source ${ }^{12}$.

Francis Fukuyama also confirms obvious truth that there is no democracy without democrats ${ }^{13}$. The malaise of the contemporary model of a democratic state can be abandoned by larger participation of citizens themselves through deliberative participation in governance. We need "democracy as cooperation"14 and "democracy of partnership"15.

Citizens should participate not only in legislative and executive power but judicial power as well, i.e. in the administration of justice and application of law by the courts. Each pillar of power requires participation of citizens. Mere check and balance principle is not sufficient to maintain balance. According to Braithwaite, we currently need a more pluralistic vision of democratic balance: "grassroots" built democracy which will be hybrid-like, that is taking citizens' opinion into account, thus being deliberative, but also contestatory (contestatory democracy). Contestatory democracy is democracy open to debate, not excluding anyone ${ }^{16}$.

Braithwaite is right emphasizing wide importance of democracy because the so called punishment normative legitimacy derives just from democracy, human rights and the rule of law ${ }^{17}$.

Currently, the meaning of the term "criminal law" is more and more arbitrary ${ }^{18}$. Nearly a century ago J. Makarewicz claimed that "the name "criminal law" corresponds to the previous social perception of the issue: a crime committed must be punished. Modern culture takes us away from this attitude ${ }^{19}$. The author indicated general mitigation of sanctions and more and more frequent renouncement of punishment. Even though he did not mean restorative justice yet, he accurately paid attention to these developing threads which turned out to be solid and which are presently referred to as well. Questions about social benefits of punishment itself are still upto-date in penal sciences. All advantages and drawbacks of imposing punishment in concreto are considered while the importance of criminal prevention is emphasized.

\footnotetext{
11 J. Braithwaite, Deliberative Republican Hybridity Through Restorative Justice, Raisons politiques. Etudes de pensée politique 2015, No. 59, p. 42.

12 F. Fukuyama, Budowanie państwa. Władza i ład międzynarodowy w XXI wieku, Poznań 2005, p. 42.

13 F. Fukuyama, Koniec historii, Kraków 2009, p. 201 et seq. Contemporary democracy has many committed opponents, comp., e.g., H.-H. Hoppe, Demokracja - bóg, który zawiódł. Ekonomia i polityka demokracji, monarchii i ładu naturalnego, Warszawa 2006.

14 Comp.: J. Dewey, The Public and Its Problems. An Essay in Political Inquiry, Penn State University Press, 2012.

15 Comp.: R. Dworkin, Is democracy possible here? Principles for a New Political Debate, Princeton University Press, 2006, p. 131 et seq.

16 Comp.: J. Braithwaite, Deliberative..., op. cit., p. 33 et seq.

17 Comp.: S. Snacken, Legitimacy of Penal Policies. Punishment between normative and empirical legitimacy, (in:) A. Crawford, A. Hucklesby (ed.), Legitimacy and Compliance in Criminal Justice, London - New York 2013, p. 61 et seq.

18 Comp. more: W. Zalewski, Sprawiedliwość naprawcza, (in:) T. Kaczmarek (ed.), System Prawa Karnego. Vol. 5. Nauka o karze. Sądowy wymiar kary, Warszawa 2014, p. 177 et seq.

19 J. Makarewicz, Prawo karne ogólne, Kraków 1914, p. 1.
} 
As early as more than a century ago, using a more adequate term than "criminal law" was suggested. For instance, "the law of crime combating" was proposed".

Changes in criminal law entail changes in the perception of justice. Retaliatory justice based on the retributive perception of "to each his own" or "may all get their due" (suum cuique), or the law of talion ("an eye for an eye") has already played its role and it is rightly becoming obsolete. The need of a different perception of justice has been expressed for a long time now. Nils Christie postulated justice based on co-participation ${ }^{21}$, which elicited a wide and positive response ${ }^{22}$. This model of justice perceives a crime mainly as defiance of social values which must be restored and redressed (value restoration). This process may be implemented through the restoration of social approval with regard to the principles and values. It considers Durkheim's revalidation of values through social approval ${ }^{23}$. According to this concept, justice means redressing values and shaping social attitudes.

In contemporary society, individual freedom has acquired such a great value that a crime and ensuing conflict must be resolved by the parties themselves rather than the State. Such thinking is based on civil law rather than previously applied criminal law approach. In this perspective, freedom is opposed to the State. As N. Christie claims: "the State has stolen the conflict from the parties and now it must give it back ${ }^{24}$. According to N. Elias, this exclusion of State coercion from the structure of penalty is an element of civilizing process in the a form of refined social control. Along this path, from penalties against life and liberty through fines we head for redress and compensation of wrongs ${ }^{25}$.

Restorative justice (hereinafter RJ) defines the issue of justice through the process and result of a specific case. RJ embraces people whose voice has been ignored so far in the criminal justice. Apart from a perpetrator, an active role therein is played by the victims, the parties' families and neighbours and sometimes representatives of local communities as in restorative justice conferencing. The success of the process is measured by a degree of satisfaction of those for whom the door has been opened. Restorative justice is faultfinding which is, most of all, expressed in the lack of trust in professional representatives of the justice system and traditional formalized proce-

Comp.: A. Thomsen, Grundriss Des Deutschen Verbrechensbekämpfungsrechtes, Enthaltend Das Deutsche Straf- Und Sonstige Bekampfungsrechts: Besonderer Teil, Struppe \& Winckler, 1905 (according to 2010 edition). Comp.: N. Christie, Granice cierpienia, Warszawa 1991, p. 112 et seq.

Only English scientific studies on this subject are counted in thousands. Comp., e.g., publications listed at: http:// restorativesolutions.us/resources/best-restorative-justice-books.

Comp.: M. Wenzel, I. Thielmann, Why We Punish in the Name of Justice: Just Desert versus Value Restoration and the Role of Social Identity, Social Justice Research, 2006, Vol. 19, No. 4, p. 450 et seq.

Comp.: N. Christie, Conflicts as property, The British Journal of Criminology 1977, No. 17, p.1 et seq.

Comp.: N. Elias, Über den Prozeß der Zivilisation, Band 1 and 2, 16, 1991, after: D. Dölling, Der Täter - Opfer - Augleich - Möglichkeiten und Grenzen einer neuen kriminalrechtlichen Reaktionsreform, JZ 1992, No. 10, p. 495. 
dures. Nevertheless, restorative justice refers to an individual criminal case; if it is satisfactorily closed, it is assumed that presumed objectives have been achieved ${ }^{26}$.

Many publications emphasize the relation between restorative justice and the republican ideals ${ }^{27}$ and depict RJ's enormous potential in promoting democracy. It is underlined that "one reason why restorative justice is popular is that it hands a little piece of power back to ordinary people"28. In this sense, restorative justice advocates limitation of the ius puniendi of states and thus the state authority's role in punishment. It implies a justice system based on a wide and active participation of differently understood communities as it turned out that there are strong relations between the model of governance and the justice system. If they are based on participation and consensus, they develop responsibility and citizenship. A punitive system does not teach democracy; it does not teach how to be a citizen. It requires people to be passive; passively accept responsibility and tolerate justice rather than participate in it. Forms of restorative justice such as circles and conferencing as RJ procedures teach active responsibility. They provide hope that the situation can be changed and cured. Here everyone has a voice which means something. They teach an $\mathrm{ABC}$ of democracy - direct participation ${ }^{29}$. Restorative justice is presented as grassroots example of civil deliberation in practice. The analogy between RJ procedures and deliberative democracy ${ }^{30}$, which has been recently so earnestly discussed, has been pointed out. In both cases, the need of conscious participation, mutual respect and amicable agreement prevails ${ }^{31}$.

Restorative justice is justice that refreshes and strengthens the parties thereto. The strategy of strengthening through reconciliation enables local communities face their need to live in peace. Strengthening a victim allows them to face their need of control and order. Strengthening a perpetrator enables them to accept liability and become responsible. The strategy of strengthening creates a possibility of inventing dynamic and innovative solutions to the problems caused by the crime, including the creation of social norms. RJ derives from specific experiences; it emphasizes the necessity to carry out research and experiments confirming legitimacy of its ideals. Despite a critique of the old paradigm, nobody, in general, pleads for the need of a total

A. Crawford, T.R. Clear, Community Justice: Transforming Communities through Restorative Justice? (in:) E. Mc-Laughilin, R. Fergusson, G. Hughes, L. Westermarland (ed.), Restorative Justice. Critical Issues, 2003, p. 215.

27 Comp.: J. Braithwaite, P. Pettit, Not Just Deserts: A Republican Theory of Criminal Justice, Oxford University Press, 1990; J. Braithwaite, Restorative Justice and Responsive Regulation, New York 2002; J. Braithwaite, Relational republican regulation, Regulation and overnance 2013, No. 7(1), p. 124-144.

28 J. Braithwaite, Encourage Restorative Justice, Criminology and Public Policy 2007, No. 6, p. 689.

29 Comp.: J. Braithwaite, Democracy, Community And Problem Solving, http://www.realjustice.org /Pages/ vt99papers/vt_brai_html.

30 Comp.: J. Parkinson, D. Roche, Restorative Justice: Deliberative Democracy in Action?, Australian Journal of Political Science 2004, No. 39(3), p. 506 et seq.

31 Comp. more: K. Kim, Restorative Justice and Deliberative Democracy: Connecting and Clarifying Foundational Norms Paper presented at the annual meeting of the MPSA Annual National Conference, Palmer House Hotel, Hilton, Chicago, IL, Apr 03, 2008, http://www.allacademic.com/meta/p265841_index.html. 
rejection of old institutions. A margin of cases which should be resolved according to the old model has been preserved ${ }^{32}$. It is obvious that restorative justice differs a lot from our repressive and punitive system of justice based on obedience. A crime is perceived as a conflict. It is underlined that a size, nature and causes of nearly every criminal conflict indicate that previous strategies of strengthening through the inclusion of the injured parties into the system of criminal justice, e.g. mediations and restitutions, must reach further and cannot be limited to the facilitation of reaching a settlement by the parties to the dispute. A structural size of a conflict indicates the need to adopt a more ambitious concept of justice. The essence of the restorative model implies deep interest not only in the redress of a wrong committed in the past but the creation of a better future as well. The future where people live in proper material, social and spiritual relations with one another. Such future requires profound insight into the factors contributing to a crime and creating conflict and injustice; it requires action which will mitigate or eliminate these factors.

Based on almost twenty years of research, Robert Putnam proved that democracy is founded on civic engagement: "to be a citizen in a community most of all means active participation in public matters" ${ }^{\prime 33}$. Full civic engagements is guaranteed by deliberative democracy, which is also called participative democracy, where citizens co-decide about every socially important issue ${ }^{34}$.

Similar to restorative justice programmes, deliberative democracy is multifaceted too. The following programmes can be enumerated here: 1 . Citizens Juries, 2 . Deliberative Opinion Polls, 3. consensus conferences, 4. Standing panels: interactive panels, 5. Community Issue Groups, 6. Standing panels: research panels, 7. Electronic democracy \& methodology, 8. Future search conferences, 9. Planning for Real, 10. Children, Young People \& Public Involvement ${ }^{35}$. All these programmes are characterized by: 1) innovation, 2) informativity (they search competent and well-informed public opinion), 3) deliberativeness (decisions and opinions are reached in an interactive discussion), 4) independence, 5) democrativeness - consulting opinions of ordinary citizens (not politicians or experts) ${ }^{36}$. Some of them are applied in Poland

Even $\mathrm{H}$. Bianchi abandoned his primary radicalism and declares a principle of "mutual limitation" of both systems. Comp. more: H. Bianchi, Justice As Sanctuary. Toward a New System of Crime Control, Eugene,Oregon,1994. R.D. Putnam, Demokracja w działaniu. Tradycje obywatelskie we współczesnych Włoszech, Kraków 1995, p. 133 et seq.

Comp. most of all: P.W. Juchacz, Idea demokracji deliberatywnej, (in:) M.N. Jakubowski, A. Szachaj, K. Abriszewski (ed.), Indywidualizm, Wspólnotowość, Polityka, Toruń 2002; P.W. Juchacz, Obywatelstwo, tożsamość, partycypacja: o idei demokracji deliberatywnej na szczeblu lokalnym, (in:) R. Piekarski (ed.), Lokalna wspólnota polityczna a zagadnienie tożsamości zbiorowej, Kraków 2002.

Ibidem, p. 66.

Presented as in: ibidem. Also comp. data available at the website of the Institute for Public Policy Research: www. ippr.org. uk. Recently A. Krzewińska, Deliberacja. Idea - metodologia - praktyka, Łódź 2016. The author discusses more: $1 /$ deliberative polls, $2 /$ community courts, $3 /$ city meetings of the 21 st century, $4 /$ open space techniques, $5 /$ deliberative cafes - ibidem, p. 115 et seq. 
- probably deliberative meetings most often, e.g. "Zszywanie miasta" ("Sewing Up the City") in Łódźz.

Thus it is apparent that restorative justice and deliberative democracy are closely related. The above mentioned relations are even stronger when we realize that the subject of a democratic debate may become and does become punishment as well ${ }^{38}$. Wide participation of citizens in criminal justice is postulated. As Albert W. Dzur noticed: "Normal, regular and active citizen action inside and outside is required for contemporary publics to consciously recognize and accept public accountability for criminal justice" 39 . Not every crime can be closed with the parties' reconciliation; in some cases punishment is necessary ${ }^{40}$ whereas restorative justice is not possible. Nevertheless, participation of community justice is possible. Its main interest is focused on a different level; above all, it considers how a criminal case or specific act have influenced the community life, which is mainly understood as neighbourhood. Undertaken action strategies are assessed with regard to the impact they exert on the local community ${ }^{41}$. Community justice takes advantage of a wider range of strategies than restorative justice schemes, including prevention. One of the preventive methods engaging citizens is, for example, Crime Prevention Through Environmental Design ${ }^{42}$.

However, the following question may arise here: if we continue to punish perpetrators but just with a wider participation of citizens than before, what is the difference between the two models? Well, the difference is significant and it implies a degree of law acceptance by all involved parties. Full acceptance may only be achieved in result of an open and free debate ${ }^{43}$. Broadly speaking: moving on to consensual positions is typical of a contemporary democratic state. According to Nicholas Thimasheff, we observe the extension of an ethical element (consensus) for the sake of a power element (coercion). In contemporary concepts of a state, this course becomes apparent in the process of democratization. If we placed the concepts of a state on a scale where a role of criminal law coercion is treated as a structuring criterion, they would create a certain continuum ranging from the concept of a totalitarian state, where violence is omnipresent, through different concepts of authoritarian state to democratic concepts of a state, that is a "welfare state", which minimizes a role of criminal law coer-

37 Comp. ibidem, p. 165 et seq.

38 Comp. P. de Greiff, Deliberative Democracy and Punishment, "Buffalo Criminal Law Review" 2002, vol. 5; A.W. Dzur, Participatory Democracy and Criminal Justice, Criminal Law and Philosophy, June 2012, p. 115 et seq., A.W. Dzur, Punishment, Participatory Democracy, and the Jury, Oxford 2012.

39 A.W. Dzur, The Priority of Participation: a Friendly Response to Professor Gargarella, "Criminal Law and Philosophy", September 2016, p. 476.

40 Comp. W. Zalewski, Przestępca „niepoprawny” - jako problem polityki kryminalnej, Gdańsk 2010.

41 A. Crawford, T.R. Clear, Community Justice..., op. cit., p. 216.

42 Comp. especially: J. Czapska (ed.), Zapobieganie przestępczości przez kształtowanie przestrzeni. Teoria. Badania. Praktyka, Kraków 2012.

43 P. de Greiff, Deliberative democracy..., op. cit., p. 377. Further comp. P. Pettit, Deliberative Democracy and the Doctrinal Paradox and R.E. Goodin, Democratic Deliberation Within, articles prepared for Deliberating about Deliberative Democracy Conference at the Law School, University of Texas, 4-6 February 2000. 
cion replacing it with new forms of coercion ${ }^{44}$. On top of this, in the contemporary computerized world, direct democracy takes advantage of new forms of communication. Citizens communicate with each other not only "above" the media but also political divisions. A new quality is emerging: participatory democracy, where a debate is grassroots and citizens are free ${ }^{45}$.

It is time for certain conclusion. The answer to the question asked in the title of this text should be positive. Restorative justice is a form of implementation of participatory democracy.

Accountability for a criminal act does attract and will attract social interest. It can be differently used. It may be idle curiosity or thirst for sensation some media feed on $^{46}$ as we pessimistically speak today about tabloid justice created by the media and influencing the shape and application of the law ${ }^{47}$. Nevertheless, interest in criminal cases may be used in a positive way by establishing deliberative framework to fulfil the objectives of justice based on co-participation.

The above outlined process does not separate an individual from the community looking after him or her; it does not distinguish between rationality and emotions, or justice and needs. It also does not rely on experts' opinions. When criminal conduct created a perpetrator and victim, RJ rather provides the most severely harmed parties with a possibility of seeking solutions. They are granted a chance they fully deserve. Aiming at a peaceful resolution of a conflict, restorative justice attempts to personalize the conflict, responsibility and the participants thereto in order to express and transform strong emotions experienced by the victim, perpetrator and community due to the committed crime. Such a way out of the crime envisages effort and involvement of the involved individuals. On the other hand, it also requires social background and the community's engagement. In a society with values emphasizing citizen participation in the affairs of state, increasing citizen participation does not require further justifications ${ }^{48}$. As Lode Walgrave somehow poetically said: "All in all, the widening river of restorative justice is becoming a delta, which irrigates the

44 A. Gryniuk, Przymus prawny. Studium socjologiczno-prawne, Toruń 1994, p. 76.

45 Comp.: D. Morris, Direct Democracy and the Internet, "Loyola of Los Angeles Law Review”, April 2001, p. 1033 et seq.

46 Comp.: Y. Jewkes, Media i przestępczość, Kraków 2010, p. 36 et seq. The author points out that: "Even the most superficial study of media coverage of crime reveals that information about crime departs both from the "reality" of crime and its share in official statistics".

47 Comp.: R.L. Fox, R.W. van Sickel, T.L. Steiger, Tabloid Justice. Criminal Justice in an Age of Media Frenzy, London 2007. The authors pessimistically conclude: "Any reform efforts that are aimed simply at regulating media behaviour or restricting press access to the courts and to police activities undoubtedly would have little impact on the tabloid justice environment. Many of the dynamics of the situation are far more complicated than simply the irresponsible conduct of the news media. Popular culture, commercial imperatives, and a complacent and unengaged citizenry have all converged to produce this set of problems" (p. 206).

B. Galaway, Informal justice: Mediation between offenders and victims, (in:) P. Albrecht, O. Backes (ed.), Crime Prevention and Intervention: Legal and Ethical Problems, New York 1989, p. 112. 
parched democracy with the participatory potential of citizens who take up responsibility to find constructive solutions" ${ }^{49}$.

\section{BIBLIOGRAPHY}

Arendt H., Korzenie totalitaryzmu, tom 1, Warszawa 1993.

Bianchi H., Justice As Sanctuary. Toward a New System of Crime Control, Eugene, Oregon 1994. Braithwaite J., Deliberative Republican Hybridity Trough Restorative Justice, "Raisons politiques. Etudes de pensée politique" 2015, No. 59.

Braithwaite J., Democracy, Community And Problem Solving, http://www.realjustice.org /Pages/ vt99papers/vt_brai_html.

Braithwaite J., Encourage Restorative Justice, “Criminology and Public Policy” 2007, No. 6. Braithwaite J., Pettit P., Not Just Deserts: A Republican Theory of Criminal Justice, Cambridge 1990. Braithwaite J., Relational republican regulation, "Regulation and Governance" 2013, No. 7(1).

Braithwaite J., Restorative Justice and Responsive Regulation, New York 2002. Christie N., Conflicts as property, "The British Journal of Criminology" 1977, No. 17.

Christie N., Granice cierpienia, Warszawa 1991.

Crawford A., Clear T.R., Community Justice: Transforming Communities through Restorative Justice?, (in:) E. McLaughilin, R. Fergusson, G. Hughes, L. Westermarland (eds.), Restorative Justice. Critical Issues, 2003.

Czapska J. (ed.), Zapobieganie przestępczości przez kształtowanie przestrzeni. Teoria. Badania. Praktyka, Kraków 2012.

Dewey J., The Public and Its Problems. An Essay in Political Inquiry, 2012.

Dölling D., Der Täter - Opfer - Augleich - Möglichkeiten und Grenzen einer neuen kriminalrechtlichen Reaktionsreform, “JZ” 1992, No. 10.

Dworkin R., Is democracy possible here? Principles for a New Political Debate, 2006.

Dzur A.W., Participatory Democracy and Criminal Justice, Criminal Law and Philosophy, June 2012. Dzur A.W., Punishment, Participatory Democracy, and the Jury, Oxford 2012.

Dzur A.W., The Priority of Participation: a Friendly Response to Professor Gargarella, Criminal Law and Philosophy, September 2016.

Elias N., Über den Prozeß der zivilisation, Band 1, 2, 16, 1991.

Fox R.L., van Sickel R.W., Steiger T.L., Tabloid Justice. Criminal Justice in an Age of Media Frenzy, London 2007.

Fukuyama F., Budowanie państwa. Władza i ład międzynarodowy w XXI wieku, Poznań 2005. Fukuyama F., Koniec historii, Kraków 2009.

Galaway B., Informal justice: Mediation between offenders and victims, (in:) P. Albrecht, O. Backes (eds.), Crime Prevention and Intervention: Legal and Ethical Problems, New York 1989.

49 Comp.: L. Walgrave, Restorative justice, Self - interest and Responsible Citizenship, Willan Publishing 2008, p. 196 
Goodin R.E., Democratic Deliberation Within, referat przygotowany na Deliberating about Deliberative Democracy Conference at the Law School, University of Texas, 4-6 February 2000.

de Greiff P., Deliberative Democracy and Punishment, "Buffalo Criminal Law Review" 2002, vol. 5. Gryniuk A., Przymus prawny. Studium socjologiczno-prawne, Toruń 1994.

Gutmann A., Identity in Democracy, Princeton 2004.

Hoppe H.-H., Demokracja - bóg, który zawiódł. Ekonomia i polityka demokracji, monarchii i ładu naturalnego, Warszawa 2006.

Jewkes Y., Media i przestępczość, Kraków 2010.

Juchacz P.W., Idea demokracji deliberatywnej, (in:) M.N. Jakubowski, A. Szachaj, K. Abriszewski (eds.), Indywidualizm, Wspólnotowość, Polityka, Toruń 2002.

Juchacz P.W., Obywatelstwo, tożsamość, partycypacja: o idei demokracji deliberatywnej na szczeblu lokalnym, (in:) R. Piekarski (ed.), Lokalna wspólnota polityczna a zagadnienie tożsamości zbiorowej, Kraków 2002.

Kim K., Restorative Justice and Deliberative Democracy: Connecting and Clarifying Foundational Norms Paper presented at the annual meeting of the MPSA Annual National Conference, Palmer House Hotel, Hilton, Chicago, IL, 3 April 2008, http://www.allacademic.com/meta/ p265841_index.html.

Krzewińska A., Deliberacja. Idea - metodologia - praktyka, Łódź 2016. Lipset S.M., Homo politicus: społeczne podstawy polityki, Warszawa 1995. Makarewicz J., Prawo karne ogólne, Kraków 1914.

Morris D., Direct Democracy and the Internet, Loyola of Los Angeles Law Review, April 2001.

Parkinson J., Roche D., Restorative Justice: Deliberative Democracy in Action?, "Australian Journal of Political Science" 2004, No. 39(3).

Peretiatkowicz A., Filozofia prawa Jana Jakóba Rousseau’a, Kraków 1913.

Pettit P., Deliberative Democracy and the Doctrinal Paradox, referat przygotowany na Deliberating about Deliberative Democracy Conference at the Law School, University of Texas, 4-6 February 2000.

Putnam R.D., Demokracja w działaniu. Tradycje obywatelskie we współczesnych Włoszech, Kraków 1995.

Putnam R.D., Samotna gra w kręgle. Upadek i odrodzenie wspólnot lokalnych w Stanach Zjednoczonych, Warszawa 2008.

Rousseau J.J., Umowa społeczna, przełożył i objaśnił dr Antoni Peratiatkowicz prof. Uniwersytetu Poznańskiego, Poznań 1920.

Snacken S., Legitimacy of Penal Policies. Punishment between normative and empirical legitimacy, (in:) A. Crawford, A. Hucklesby (eds.), Legitimacy and Compliance in Criminal Justice, London New York 2013.

Thomsen A., Grundriss Des Deutschen Verbrechensbekämpfungsrechtes, Enthaltend Das Deutsche Straf- Und Sonstige Bekampfungsrechts: Besonderer Teil, Struppe \& Winckler, 1905.

Walgrave L., Restorative justice, Self-interest and Responsible Citizenship, Willan Publishing 2008.

Wenzel M., Thielmann I., Why We Punish in the Name of Justice: Just Desert versus Value Restoration and the Role of Social Identity, "Social Justice Research" 2006, tom 19, No. 4. 
Wojciechowski B., Interkulturowe prawo karne. Filozoficzne podstawy karania w wielokulturowych społeczeństwach demokratycznych, Toruń 2009.

Wróblewski B., Penologia. Socjologia kar, tom I, Wilno 1926.

Zalewski W., Przestępca “niepoprawny” - jako problem polityki kryminalnej, Gdańsk 2010.

Zalewski W., Sprawiedliwość naprawcza, (in:) T. Kaczmarek (ed.), System Prawa Karnego, tom 5, Nauka o karze. Sądowy wymiar kary, Warszawa 2014.

Zieliński E., Nauka o państwie i polityce, Warszawa 2001. 